\title{
KONKURENCYJNOŚĆ PAŃSTW \\ AZJI CENTRALNEJ W ICH RELACJACH HANDLOWYCH Z UNIĄ EUROPEJSKĄ I CHINAMI
}

Współcześnie, w dobie nasilającej się rywalizacji ekonomicznej mocarstw, w tym Unii Europejskiej oraz Chin, szczególnego znaczenia nabiera region Azji Centralnej, który tworzy pięć państw, tj. Kazachstan, Kirgistan, Tadżykistan, Turkmenistan oraz Uzbekistan. W ostatnich latach szczególnie aktywne są w tym regionie Chiny, także za sprawą realizacji tzw. Inicjatywy Pasa i Szlaku (Belt and Road Initiative $B R I)$. Unia Europejska, podobnie jak USA czy Rosja, także chce zabezpieczyć oraz wzmocnić swoje wpływy w Azji Centralnej. Bez wattpienia, wynik owej gry o wpływy i pozycję będzie zależał m.in. od siły gospodarczej państw Azji Centralnej oraz poziomu ich konkurencyjności we współczesnym świecie, czego egzemplifikacją są posiadane przewagi komparatywne w handlu międzynarodowym. Nie bez znaczenia w tym kontekście będzie także realizacja wspomnianej już chińskiej Inicjatywy Pasa i Szlaku, której oczekiwanym efektem jest poprawa infrastruktury transportowej w państwach Azji Centralnej, a tym samym ułatwienie ich kontaktów handlowych zarówno z Chinami, jak i z państwami Unii Europejskiej.

Celem artykułu jest: 1) określenie znaczenia UE oraz Chin jako rynków zbytu dla towarów z państw Azji Centralnej, 2) określenie profili konkurencyjnych gospodarek państw Azji Centralnej poprzez zidentyfikowanie posiadanych przez nie przewag komparatywnych w handlu międzynarodowym, 3) zidentyfikowanie potencjalnych obszarów współpracy i/lub rywalizacji w relacjach handlowych państw Azji Centralnej z UE oraz Chinami.

Punktem wyjścia do rozważań jest teza, zgodnie z którą poziom konkurencyjności gospodarek państw Azji Centralnej we współczesnym handlu międzynarodowym jest stosunkowo niski i do tego mocno ograniczony co do struktury posiadanych przewag komparatywnych. Niemniej jednak posiadane przewagi komparatywne z jednej strony państw Azji Centralnej, z drugiej UE oraz Chin, jako komplementarne wobec siebie, pozwalają zakładać, że występują obiektywne przesłanki do rozwoju i pogłębiania współpracy handlowej, która będzie korzystna dla każdej ze stron.

ORCID: 0000-0002-4639-0118, DOI: 10.4467/23538724GS.20.023.12141 


\section{Stan badań nad konkurencyjnością państw Azji Centralnej}

Problematyka konkurencyjności państw Azji Centralnej w handlu międzynarodowym w kompleksowym ujęciu komparatystycznym jako całego regionu w literaturze ekonomicznej de facto pojawia się bardzo rzadko. Zdecydowanie częściej bowiem można znaleźć analizy konkurencyjności poszczególnych państw Azji Centralnej z osobna. Liderem w tym zakresie jest bez wattpienia Kazachstan, skądinąd największa pod względem wielkości gospodarka regionu Azji Centralnej. Odnosząc się do międzynarodowej konkurencyjności tego kraju, bardzo często podkreśla się jego duże uzależnienie od posiadanych surowców ${ }^{1}$. Irena Macerinskiene i Gaukhar Sakhanova stwierdzają wprost, że główna przewagą konkurencyjną Kazachstanu są jego ogromne rezerwy surowców mineralnych, a także stabilna sytuacja makroekonomiczna. Dodatkowo identyfikują one także główne słabości kazachskiej gospodarki, które wymiernie obniżają jej międzynarodową konkurencyjność, tj. niską zdolność do innowacji oraz wysoki wskaźnik korupcji ${ }^{2}$.

W przypadku konkurencyjności Kazachstanu należy podkreślić, że mimo posiadania pewnych przewag komparatywnych w zakresie handlu surowcami mineralnymi (paliwa mineralne stanowią ponad 80\% kazachskiego eksportu) ogólna konkurencyjność tego państwa znacznie zmniejszyła się na przestrzeni ostatnich lat, co wynika z badań m.in. A. Khatibiego ${ }^{3}$. Do podobnych wniosków doszły też A. Amirbekova i D. Madiyarova ${ }^{4}$. Jedną z przyczyn owej sytuacji był nie tylko wzrost ogólnego poziomu konkurencji we współczesnej gospodarce światowej, ale również niekorzystne tendencje cenowe na światowych rynkach, zwłaszcza surowców energetycznych ${ }^{5}$. Z kolei jak podkreśla G. Nurmukhanova, z punktu widzenia obecnego profilu konkurencyjnego Kazachstanu kluczowy dla przyszłego rozwoju kraju będzie strategiczny wybór między dotychczasową orientacją

1 K. Falkowski, The Resources-Dependent Competitive Profile of Kazakhstan and its Consequences for the Country's Future Development, „Prace Naukowe Uniwersytetu Ekonomicznego we Wrocławiu” 2017, nr 486, s. 92-102; M. Matveev, Economic priorities of Kazakhstan during global crisis waves, „Creative Economy” 2011, vol. 5, no. 5, s. 3-8.

2 I. Macerinskiene, G. Sakhanova, National Economy Competitiveness of Kazakhstan Republic, „Engineering Economics" 2011, vol. 22, no. 3, s. 292-299.

3 A. Khatibi, Karakehstan's Revealed Comparative Advantage Vis-à-vis the EU-27, „ECIPE Working Paper" 2008, no. 3.

4 A. Amirbekova, D. Madiyarova, Assessment of the Competitiveness of Kazakisstan's Exports, „Mediterranean Journal of Social Sciences” 2015, vol. 6, no. 6, s. 443-447.

5 N. Alzhanova, Macroeconomic Stability as a Factor of Competitiveness: Case of Kazakhstan, „World Applied Sciences Journal” 2013, vol. 26, no. 5, s. 692-696. 
surowcową a orientacją gospodarki na innowacje $\mathrm{i}$ technologie ${ }^{6}$. W tym samym duchu wypowiada się R. Danabayeva, według której jako kraj o bogatych zasobach naturalnych Kazachstan wciąż stoi przed wyzwaniami związanymi z przekształceniem się z gospodarki surowcowej w gospodarkę opartą na wiedzy ${ }^{7}$. Co prawda, można zauważyć, że pożądany proces owej niezbędnej transformacji dokonuje się obecnie w Kazachstanie na fali dynamicznego rozwoju gospodarczego tego kraju, niemniej dzieje się to zdecydowanie wolniej, aniżeli zakładano w dokumentach rządowych ${ }^{8}$.

Z kolei w odniesieniu do badań nad konkurencyjnością Kirgistanu w handlu międzynarodowym warto przywołać pracę B. Mamadieva. Dowodzi on, że Kirgistan po odzyskaniu niepodległości w 1991 r., co umożliwiło mu swobodny handel z resztą świata, nie był w stanie wykorzystać tego dla rozwoju własnej gospodarki, ponieważ ta była całkowicie niekonkurencyjna? . Do podobnego wniosku doszli także inni badacze, stwierdzając, że po 1991 r. kraj ten doświadczył długotrwałej i głębokiej recesji, która praktycznie doprowadziła do niemal całkowitej erozji jego bazy przemysłowej ${ }^{10}$. Co więcej, silne uzależnienie kirgiskiej gospodarki od trzech głównych źródeł dochodu, a mianowicie eksploatacji i eksportu zasobów naturalnych ${ }^{11}$, przekazów pieniężnych od emigrantów zarobkowych oraz pożyczek zagranicznych, siłą rzeczy wymiernie w negatywny sposób wpłynęło na zdolność konkurencyjną, a w konsekwencji obniżyło międzynarodową pozycję gospodarczą państwa ${ }^{12}$.

Już we wcześniejszej publikacji przeprowadziłem szczegółową analizę konkurencyjności gospodarki Kirgistanu w handlu międzynarodowym. W swoim badaniu dowiodłem, że kraj ten jest bardzo mało konkurencyjny, a jedyne przewagi komparatywne ma w zakresie handlu towarami średnio-niskiej techniki, w szczególności

${ }^{6}$ G. Nurmukhanova, Competitiveness of national economy: problems of regulation, „E+ M Ekonomie a Management" 2008, vol. 11, no. 4, s. 35-39.

7 R. Danabayeva, Management of Innovation in the Modern Kazakisstan: Development Priorities of Science, Technology and Innovation, „Journal of Information Systems \& Operations Management” 2013, vol. 7, no. 2, s. 288-293.

8 K. Falkowski, The Resources-Dependent Competitive Profile..., s. 92-102; S.H. Bhuiyan, Transition Towards a Knowledge-Based Society in Post-Communist Kazakhstan: Does Good Governance Matter?, „Journal of Asian and African Studies" 2011, vol. 46, no. 4, s. 404-421.

9 B. Mamadiev, Competitiveness analysis of Kyrgyzstan using Porter's diamond, ,Journal of Qafqaz University” 2013, vol. 2, no. 1, s. 131-137.

10 E. Rovenskaya, E. Sedighi, N. Komendantova, N. Strelkovskii, S. Sizov, N. Karabashov, N. Atakanov, U. Chekirbaev, Z. Zheenaliev, A. Stepanova, L. Ekenberg, F.S. Rodriguez, Industrial Development of Kyrgyzstan: Background, „Working Paper”, International Institute for Applied Systems Analysis, Luxemburg 2018.

11 Kirgistan jest bogaty w surowce mineralne, posiada zwłaszcza znaczne złoża węgla, złota, uranu, antymonu i innych cennych metali, ale występują tu znikome ilości ropy naftowej i gazu ziemnego, które z konieczności musi importować.

12 E. Rovenskaya et al., Industrial Development... 
towarami z kategorii podstawowe metale i metalowe wyroby gotowe oraz tzw. inne niemetaliczne wyroby mineralne ${ }^{13}$.

Również konkurencyjność Tadżykistanu w handlu międzynarodowym nie jest wysoka, a co więcej, na przestrzeni ostatnich lat znacznie spadła. Było to spowodowane głównie brakiem zdywersyfikowanej oferty eksportowej, zaś przede wszystkim utrzymująca się niezwykle silną zależnością kraju od produkcji oraz eksportu bawełny i aluminium. To właśnie tadżyckie towary o niskim stopniu przetworzenia oraz wartości dodanej charakteryzują się w tym przypadku relatywnie największą konkurencyjnością na rynkach międzynarodowych ${ }^{14}$.

Warto także podkreślić za Organizacją Współpracy Gospodarczej i Rozwoju (OECD), że duże znaczenie dla Tadżykistanu ma szeroko rozumiany sektor rolny, który odpowiada za 25\% PKB kraju, 39\% dochodów podatkowych i około 50\% całkowitego zatrudnienia. Ponadto 70\% ludności mieszka na obszarach wiejskich, chociaż grunty orne zajmuja jedynie 7\% terytorium kraju. W czasach ZSRR produkcja rolna Tadżykistanu była monokultura surowej bawełny. Od 1991 r. modele upraw częściowo się zmieniły, a zboża i rośliny strączkowe zyskały na znaczeniu. W konsekwencji dzisiaj pszenica i pasza zajmują odpowiednio 35\% i 15\% całkowitej powierzchni zasiewów w Tadżykistanie. Jednak niska powierzchnia gruntów ornych, złe połączenia między rynkami zbytu towarów oraz obszarami produkcji rolnej, jak również niska wydajność sprawiaja, że tadżyckie rolnictwo jest nisko konkurencyjne na arenie międzynarodowej ${ }^{15}$.

Z kolei odnosząc się do istniejących badań nad konkurencyjnością Uzbekistanu, warto podkreślić, że jego konkurencyjność eksportowa, podobnie jak innych państw Azji Centralnej, stopniowo pogarszała się na przestrzeni ostatniej dekady. Słabe otoczenie biznesowe oraz niski poziom rozwoju uniemożliwiły Uzbekistanowi szybką integrację z globalnymi łańcuchami wartości ${ }^{16}$. Niemniej, na co zwraca uwagę OECD, Uzbekistan zajmuje stosunkowo silną pozycję konkurencyjną w handlu międzynarodowym w zakresie produktów rolnych, w szczególności bawełny, a także - choć w dużo mniejszym zakresie - świeżych owoców i warzyw ${ }^{17}$. Notabene, warto podkreślić istotne znaczenie sektora rolnego dla gospodarki Uzbekistanu,

13 K. Falkowski, Long-Term Comparative Advantages of the Eurasian Economic Union Member States in International Trade, „International Journal of Management and Economics” 2017, vol. 53, no. 4, s. $27-49$.

14 ADB, Tajikistan. Promoting Export Diversification and Growth. Country Diagnostic Study, Asian Development Bank, Manila 2016.

15 OECD, Monitoring competitiveness reforms in Tajikistan, Paris 2018; V. Strokova, M.I. Ajwad, Jobs Diagnostic: Tajikistan - Strategic framework for Jobs, World Bank, Washington, DC 2017.

16 L. Burunciuc, W. Fengler, W. Schloemer, D. Taglioni, How Uzbekistan is transforming into an open economy, World Bank; Brookings Institution, Washington, DC 2018.

17 OECD, Enhancing Competitiveness in Central Asia, Competitiveness and Private Sector Development, Paris 2018. 
o czym najlepiej świadczy około osiemnastoprocentowy udział tego sektora w uzbeckim PKB oraz ponad trzydziestoprocentowy w zatrudnieniu ogółem. Co więcej, na przestrzeni lat 2000-2018 wartość eksportu towarów rolnych Uzbekistanu wzrosła z ok. 520 mln USD do 2,8 mld USD ${ }^{18}$.

Odnosząc się do handlu towarami rolnymi w Uzbekistanie, warto przywołać także wyniki badań A. Ortikova, L. Smutki i I. Benesovej. Wynika z nich, że struktura geograficzna tego handlu stała się na przestrzeni ostatnich lat coraz mniej zdywersyfikowana ${ }^{19}$. Uszczegółowiają to J. Oh, B. Yuldashev oraz S.H. Moon, dowodząc, że handel tymi towarami w przypadku Uzbekistanu koncentruje się de facto na Ukrainie i Rosji w eksporcie oraz Chinach i Korei Południowej w imporcie, podczas gdy jego kontakty handlowe z sąsiadami zrzeszonymi we Wspólnocie Niepodległych Państw, zwłaszcza z Tadżykistanem, Kazachstanem, Kirgistanem i Azerbejdżanem, są bardzo wyraźnie zaniedbywane ${ }^{20}$.

Jednocześnie, jak dowodzą V. Popov i A. Chowdhury, odnotowuje się w Uzbekistanie stopniowy wzrost udziału przemysłu w PKB oraz udziału maszyn i urządzeń w produkcji przemysłowej ${ }^{21}$. Ponadto, w ostatnich latach kraj ten zaczą 1 bardzo wyraźnie promować swój przemysł chemiczny, zwłaszcza produkcję paliw syntetycznych i wyrobów z polipropylenu z gazu ziemnego. Powyższe zmiany należy ocenić pozytywnie z punktu widzenia międzynarodowej konkurencyjności uzbeckiej gospodarki. Oznaczają bowiem jej transformację w kierunku sektorów o wyższej wartości dodanej. Nie da się jednak skutecznie podnieść konkurencyjności gospodarki Uzbekistanu, jak twierdzi Europejski Bank Odbudowy i Rozwoju, bez zwiększania roli sektora prywatnego, jak również wzmocnienia instytucji demokratycznych w kraju, rozszerzenia roli społeczeństwa obywatelskiego, zapewnienia większej wolności środkom masowego przekazu i promowania przedsiębiorczości kobiet ${ }^{22}$.

W przypadku ostatniego z analizowanych w niniejszym artykule państw Azji Centralnej, tj. Turkmenistanu, z uwagi na brak wiarygodnych danych nie ma w literaturze badań i analiz ekonomicznych poświęconych konkurencyjności tamtejszej gospodarki. Jest to kraj, którego gospodarka opiera się praktycznie wyłącznie na sprzedaży gazu ziemnego (Turkmenistan posiada czwarte co do wielkości na

\footnotetext{
18 A. Ortikov, L. Smutka, I. Benesova, Competitiveness of Uz̧bek. Agrarian Foreign Trade - Different Regional Trade Blocs and the Most Significant Trade Partners, „Journal of International Studies” 2019, vol. 12, no. 4, s. 177-194.

19 Ibidem.

$20 \mathrm{~J}$. Oh, B. Yuldashev, S.H. Moon, Where is Uzbekistan's trade and where should it be directed? Gravity analyses for being doubly landlocked, „International Area Studies Review” 2018, vol. 21, no. 1, s. 68-84.

${ }^{21}$ V. Popov, A. Chowdhury, What can Uzbekistan tell us about industrial policy that we did not already know?, „DESA Working Paper”, no. 147, New York 2016.

22 EBRD, Transition Report 2019-20, London 2019.
} 
świecie potwierdzone zasoby gazu ziemnego oraz drugie co do wielkości pole gazowe na świecie „Galkynysh” w południowo-wschodniej części kraju) oraz ropy naftowej i jedynie w tym zakresie można mówić o posiadanych przez Turkmenistan przewagach konkurencyjnych w handlu międzynarodowym ${ }^{23}$.

Reasumując, syntetyczny przegląd literatury ekonomicznej dotyczącej problematyki konkurencyjności państw Azji Centralnej w handlu międzynarodowym pozwala dostrzec bardzo wyraźny brak komparatystycznych, kompleksowych badań obejmujących wszystkie państwa regionu. Jeśli zaś już takowe się pojawiają, to dotyczą one w zdecydowanej większości jedynie gospodarki Kazachstanu. Brakuje też analiz, które podejmowałyby problematykę międzynarodowej konkurencyjności tej grupy państw w kontekście ich relacji handlowych z Unią Europejską oraz Chinami. Tym samym w pełni uzasadnione wydaje się podjęcie w niniejszym artykule analizy przedmiotowego zagadnienia. $Z$ jednej strony pozwoli to uzupełnić istniejąca lukę badawczą w tym zakresie, z drugiej zaś rzuci światło na podłoże ekonomicznej rywalizacji UE oraz Chin na obszarze Azji Centralnej.

\section{Zastosowana metoda badawcza}

Pojęcie międzynarodowej konkurencyjności jest bardzo różnie definiowane w literaturze ekonomicznej, w zależności od tego, kto (firmy czy państwa), na jakim poziomie (mikro, mezo, makro) i w jakim zakresie (w sferze czynników wytwórczych, w sferze produktów) konkuruje $z$ innymi podmiotami na arenie międzynarodowej. Syntetycznego przeglądu tych definicji dokonali m.in. P. Bhawsar i U. Chattopadhyay ${ }^{24}$.

Definiując $z$ kolei na potrzeby niniejszego artykułu pojęcie konkurencyjności gospodarki w handlu międzynarodowym, za OECD można stwierdzić, że jest to zdolność danej gospodarki do uczciwej i skutecznej konkurencji na międzynarodowych rynkach towarów i usług, co w konsekwencji prowadzi do poprawy poziomu życia obywateli danego kraju w dłuższej perspektywie ${ }^{25}$. Dodatkowo M. Weresa podkreśla dynamiczny charakter owej konkurencyjności, twierdząc, że jest ona zdolnością do szybszego niż inne kraje osiagania większych korzyści z własnych i zagranicznych czynników produkcji w warunkach otwarcia gospodarki ${ }^{26}$. W mo-

23 Overseas Business Risk - Turkmenistan, Department for International Trade, London 2019.

24 P. Bhawsar, U. Chattopadhyay, Competitiveness: Review, Reflections and Directions, „Global Business Review" 2015, vol. 16(4), s. 665-679.

25 OECD Glossary of Statistical Terms, http://stats.oecd.org/glossary/detail.asp?ID=399 (dostęp: 12.04.2020).

${ }^{26}$ Innovation, Human Capital and Trade Competitiveness. How Are They Connected and Why Do They Matter?, ed. M.A. Weresa, Springer International Publishing, 2014. 
jej ocenie konkurencyjność gospodarki w handlu międzynarodowym to zdolność danego kraju, rozumianego jako cały system społeczno-polityczno-ekonomiczny, do uzyskania określonych przewag konkurencyjnych w zakresie międzynarodowych rynków czynników produkcji oraz rynków zbytu towarów i usług, a także ich permanentnej poprawy w warunkach dynamicznie zmieniającego się otoczenia międzynarodowego ${ }^{27}$.

Mając świadomość istnienia różnorodnych metod oceny poziomu konkurencyjności gospodarek w handlu międzynarodowym ${ }^{28}$, w niniejszym opracowaniu zastosowano tradycyjną i często stosowaną metodę analizy ujawnionych przewag komparatywnych B. Balassy ${ }^{29} \mathrm{w}$ postaci:

$$
\mathrm{RCA}_{i j}=\frac{x_{i j}}{\sum_{i} x_{i j}} / \frac{\sum_{j} x_{i j}}{\sum_{j} \sum_{i} x_{i j}}
$$

gdzie:

$\mathrm{RCA}_{i j}$ - wskaźnik ujawnionych przewag komparatywnych danego kraju dla grupy towarowej $i$ w stosunku do kraju lub grupy krajów $j$,

$x_{i j} \quad$ - eksport grupy towarowej $i$ z danego kraju do kraju lub grupy krajów $j$,

$\sum_{i} x_{i j} \quad$ - eksport ogółem $z$ danego kraju do kraju lub grupy krajów $j$,

$\sum_{j} x_{i j} \quad-$ eksport grupy towarowej $i$ z kraju lub grupy krajów $j$,

$\sum_{j} \sum_{i} x_{i j}-$ eksport ogółem z kraju lub grupy krajów $j$.

Wartość wskaźnika $\mathrm{RCA}_{i j}>1$ świadczy o występowaniu ujawnionej przewagi względnej w handlu daną grupą towarową i wskazuje na intensywność tej przewagi. Z kolei w przypadku wskaźników $\mathrm{RCA}_{i j}$ z przedziału $(0 ; 1\rangle$ mamy do czynienia z brakiem tego typu przewagi o mniejszej lub większej intensywności.

Dokonana analiza konkurencyjności państw Azji Centralnej w kontekście ich relacji handlowych z Unią Europejską oraz Chinami obejmuje lata 2008-2018. $\mathrm{Z}$ kolei dane wykorzystane do analizy przedmiotowego zagadnienia pochodzą głównie z bazy danych Banku Światowego i United Nations Commodity Trade Statistics Database.

${ }^{27}$ K. Falkowski, The importance of energy resources for Azerbaijan's international competitiveness, ,Journal of International Studies" 2018, vol. 11, no. 4, s. 46, 47.

28 G. Startiene, R. Remeikiene, Evaluation of Revealed Comparative Advantage of Lithuanian Industry in Global Markets, „Procedia - Social and Behavioral Sciences” 2014, vol. 110, s. 428-438.

29 B. Balassa, Revealed' Comparative Advantage Revisited [w:] Comparative Advantage, Trade Policy and Economic Development, ed. B. Balassa, New York 1989, s. 63-79; eadem, Trade Liberalization and Revealed' Comparative Advantage, ,The Manchester School of Economic and Social Studies” 1965, no. 33 . 


\section{Znaczenie Unii Europejskiej oraz Chin jako rynków zbytu towarów z państw Azji Centralnej}

Zarówno Unia Europejska, jak i Chiny są ważnymi partnerami handlowymi dla państw Azji Centralnej. Należy jednak pamiętać, że w drugą stronę jest bardzo podobnie. Dzieje się tak nie tylko dlatego, że region Azji Centralnej jest bogaty w surowce, w tym surowce energetyczne, co ma znaczenie z punktu widzenia dynamicznie rozwijających się Chin, jak również UE starającej się uskuteczniać politykę dywersyfikacji źródeł pozyskiwania owych surowców, ale także z uwagi na jego położenie geograficzne, a mówiąc dokładniej, strategiczne położenie geopolityczne.

Odzwierciedleniem rosnącego zainteresowania regionem Azji Centralnej ze strony UE i Chin oraz wzrostu znaczenia powiązań handlowych pomiędzy nimi jest wyraźny wzrost wzajemnych obrotów handlowych na przestrzeni lat 2008-2018. Był on szczególnie widoczny w przypadku Chin - wartość całkowitych obrotów handlowych państw Azji Centralnej z Chinami w tym okresie uległa więcej niż podwojeniu (rys. 1). Dzisiaj to Chiny są niekwestionowanym liderem w wymianie handlowej regionu Azji Centralnej.

Wzrost obrotów handlowych nastąpił również w przypadku Unii Europejskiej (36,5 mld USD w 2018 r. wobec 31,5 mld USD w 2008 r.), aczkolwiek nie był on tak znaczący jak w przypadku Chin. Trzeba jednak pamiętać, że już w 2008 r. obroty handlowe EU z państwami Azji Centralnej były wysokie (blisko dwukrotnie większe niż Chin z państwami Azji Centralnej). Dla porównania na rys. 1 przedstawiono także stosowne dane dla Rosji, która w latach 90. XX wieku, tuż po rozpadzie ZSRR, była głównym partnerem handlowym państw Azji Centralnej, a następnie tę silna pozycją handlową stopniowo traciła.

Znaczenie handlowe UE i Chin dla poszczególnych państw regionu Azji Centralnej jest silnie zróżnicowane (rys. 2). Oba te rynki łącznie w eksporcie państw Azji Centralnej odgrywają największą rolę w odniesieniu do Kazachstanu i Turkmenistanu. W 2018 r. udział UE i Chin w eksporcie Kazachstanu wyniósł nieco ponad 75\%, zaś w eksporcie Turkmenistanu niemal 80\%. Warto podkreślić, że o ile gros eksportu z Kazachstanu trafia na rynki UE, o tyle w przypadku Turkmenistanu jest odwrotnie - to Chiny są głównym adresatem towarów eksportowanych z tego kraju. Taka sytuacja jest konsekwencja prowadzonej w obu krajach zagranicznej polityki gospodarczej.

Znaczenie unijnego oraz chińskiego rynku zbytu jest także stosunkowo duże dla towarów eksportowanych z Uzbekistanu i Kirgistanu. W 2018 r. udział UE oraz Chin łącznie w uzbeckim eksporcie wynosił bowiem ok. 47\%, zaś w Kirgistanie ok. 44\%. Zdecydowanie zaś najmniejszą rolę wspomniane rynki zbytu odgrywają w Tadżykistanie (analogiczny udział w 2018 r. wyniósł ok. 31\%). Co ciekawe, w przypadku tych trzech państw znaczenie UE było relatywnie większe aniżeli Chin. Jest to szczególnie 
widoczne w odniesieniu do Kirgistanu i Tadżykistanu. Nie zmienia to faktu, że wzrost gospodarczego znaczenia Chin we wszystkich państwach Azji Centralnej w ostatniej dekadzie jest bezsporny, w efekcie czego stopniowo rośnie znaczenie chińskiego rynku zbytu dla towarów z Azji Centralnej, zwłaszcza surowców i żywności.

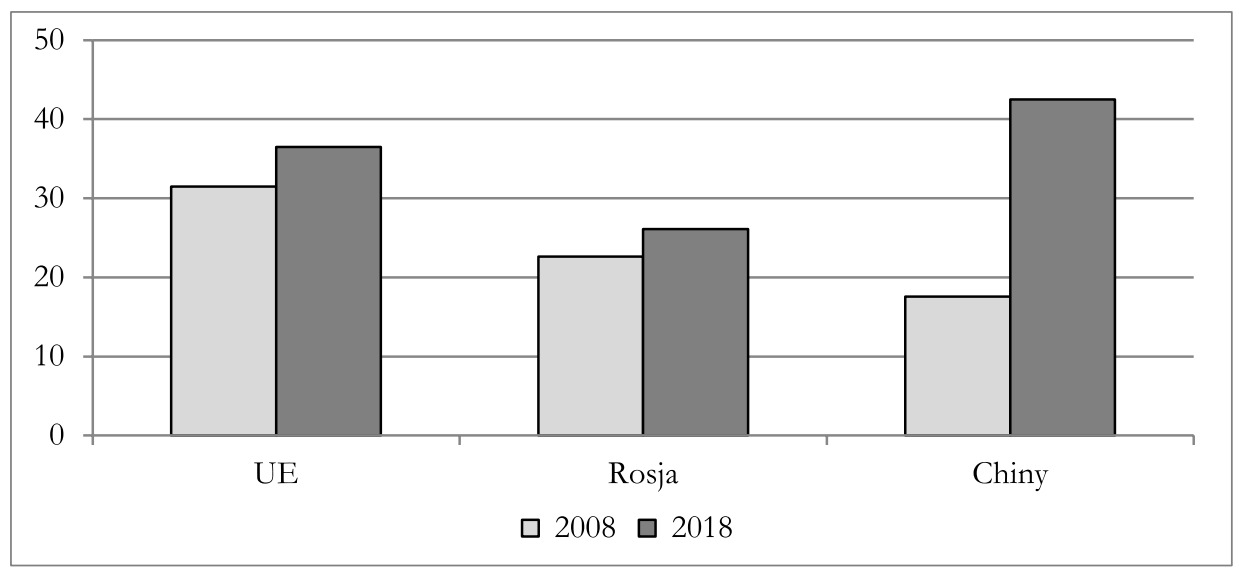

Rys. 1. Wartość obrotów handlowych ogółem państw Azji Centralnej z EU, Rosją i Chinami w 2008 oraz 2018 r. (mld USD)

Źródło: Opracowanie własne na podstawie danych Banku Światowego.

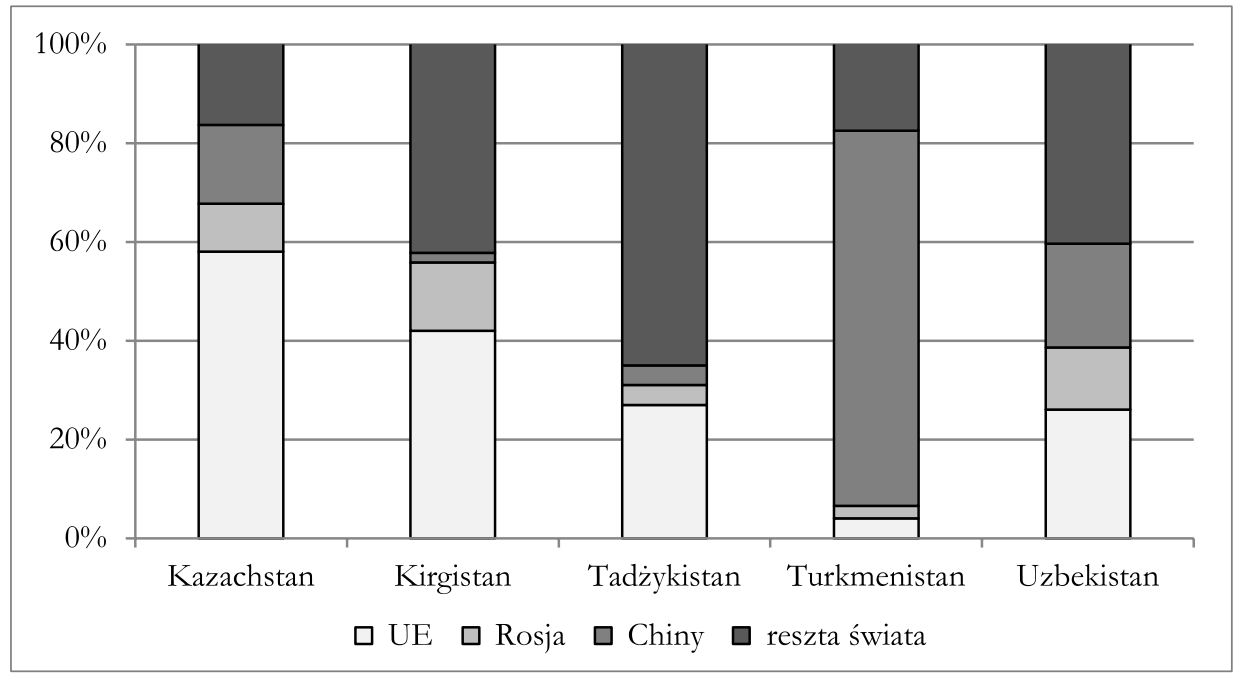

Rys. 2. Udział UE, Rosji i Chin w eksporcie poszczególnych państw Azji Centralnej w 2018 r. Źródło: Opracowanie własne na podstawie danych Banku Światowego. 


\section{Profile konkurencyjne państw Azji Centralnej w handlu międzynarodowym}

Poziom konkurencyjności państw Azji Centralnej we współczesnym handlu międzynarodowym jest stosunkowo niski i do tego mocno ograniczony co do struktury posiadanych, relatywnie nielicznych przewag komparatywnych. Wszystkie te państwa bez wyjątku posiadają owe przewagi jedynie w zakresie towarów o stosunkowo niskim stopniu zaawansowania technologicznego, niskiej wartości dodanej, kapitałochłonnych oraz pochodzących z przemysłów wykorzystujących średnio wykwalifikowanych pracowników fizycznych (tab. 1). W ich swoistym profilu konkurencyjnym, determinowanym posiadanymi ujawnionymi przewagami komparatywnymi (RCA), dominują bowiem paliwa, minerały, metale, warzywa, a także tekstylia i odzież.

Tabela 1. Ujawnione przewagi komparatywne (RCA) państw Azji Centralnej w handlu międzynarodowym na przestrzeni lat 2008-2018

\begin{tabular}{|c|c|}
\hline Kraj & Rodzaj grupy towarowej \\
\hline Kazachstan & $\begin{array}{l}\text { 1. } \text { paliwa } \\
\text { 2. } \text { minerały } \\
\text { 3. metale } \\
\text { 4. } \text { warzywa }\end{array}$ \\
\hline Kirgistan & $\begin{array}{l}\text { 1. kamień i szkło } \\
\text { 2. minerały } \\
\text { 3. skóry } \\
\text { 4. warzywa } \\
\text { 5. tekstylia i odzież }\end{array}$ \\
\hline Tadżykistan & $\begin{array}{l}\text { 1. metale } \\
\text { 2. tekstylia i odzież } \\
\text { 3. warzywa } \\
\text { 4. żywność }\end{array}$ \\
\hline Turkmenistan & $\begin{array}{l}\text { 1. paliwa } \\
\text { 2. tekstylia i odzież }\end{array}$ \\
\hline Uzbekistan & $\begin{array}{l}\text { 1. kamień i szkło } \\
\text { 2. warzywa } \\
\text { 3. tekstylia i odzież } \\
\text { 4. paliwa } \\
\text { 5. metale }\end{array}$ \\
\hline
\end{tabular}

Źródło: Opracowanie własne na podstawie danych United Nations Commodity Trade Statistics Database. 
Posiadane przewagi komparatywne znajduja swoje pełne odzwierciedlenie w strukturze towarowej eksportu poszczególnych państw Azji Centralnej (tab. 2).

Tabela 2. Towary o największym znaczeniu w eksporcie państw Azji Centralnej w 2018 r.

\begin{tabular}{|c|c|c|}
\hline Kraj & $\begin{array}{c}\text { Pięć głównych grup towarowych } \\
\text { w eksporcie według klasyfikacji } \\
\text { HS } 2 \text { (\% eksportu ogółem) }\end{array}$ & $\begin{array}{c}\text { Pięć głównych grup towarowych } \\
\text { w eksporcie według klasyfikacji } \\
\text { HS } 4 \text { (\% eksportu ogółem) }\end{array}$ \\
\hline Kazachstan & $\begin{array}{l}\text { 1. paliwa mineralne, w tym ropa } \\
\text { naftowa }(70,1 \%) \\
\text { 2. żelazo, stal }(6,8 \%) \\
\text { 3. miedź }(4,2 \%) \\
\text { 4. chemikalia nieorganiczne }(3,5 \%) \\
\text { 5. rudy metali, żużel, popiół }(3,4 \%)\end{array}$ & $\begin{array}{l}\text { 1. ropa naftowa }(62 \%) \\
\text { 2. gaz ziemny }(4,9 \%) \\
\text { 3. miedź rafinowana i nieobrobione } \\
\text { plastycznie stopy }(4 \%) \\
\text { 4. żelazostopy }(3,6 \%) \\
\text { 5. radioaktywne pierwiastki } \\
\text { chemiczne }(2,2 \%)\end{array}$ \\
\hline Kirgistan & $\begin{array}{l}\text { 1. klejnoty, metale szlachetne } \\
(40,2 \%) \\
\text { 2. paliwa mineralne, w tym ropa } \\
\text { naftowa }(8,2 \%) \\
\text { 3. odzież z dzianiny lub } \\
\text { szydełkowana }(8,1 \%) \\
\text { 4. rudy metali, żużel, popiół }(7,4 \%) \\
\text { 5. warzywa }(3,7 \%)\end{array}$ & $\begin{array}{l}\text { 1. złoto }(39,3 \%) \\
\text { 2. rudy metali szlachetnych } \\
\text { i koncentraty }(7,4 \%) \\
\text { 3. damskie bluzki i koszule }(5,6 \%) \\
\text { 4. oleje ropy naftowej }(5 \%) \\
\text { 5. suszone warzywa łuskane }(3,3 \%)\end{array}$ \\
\hline Tadżykistan & $\begin{array}{l}\text { 1. rudy metali, żużel, popiół }(26,6 \%) \\
\text { 2. klejnoty, metale szlachetne } \\
(20,2 \%) \\
\text { 3. bawełna }(16,3 \%) \\
\text { 4. aluminium }(16,2 \%) \\
\text { 5. sól, siarka, kamień, cement }(6,1 \%)\end{array}$ & $\begin{array}{l}\text { 1. złoto }(20,1 \%) \\
\text { 2. aluminium }(15,7 \%) \\
\text { 3. bawełna surowa }(12,5 \%) \\
\text { 4. rudy i koncentraty cynku }(11,5 \%) \\
\text { 5. rudy i koncentraty ołowiu }(10,5 \%)\end{array}$ \\
\hline Turkmenistan & $\begin{array}{l}\text { 1. paliwa mineralne, w tym ropa } \\
\text { naftowa }(92,7 \%) \\
\text { 2. bawełna }(3,3 \%) \\
\text { 3. sól, siarka, kamień, cement }(0,8 \%) \\
\text { 4. tworzywa sztuczne, wyroby } \\
\text { z tworzyw sztucznych }(0,7 \%) \\
\text { 5. nawozy }(0,6 \%)\end{array}$ & $\begin{array}{l}\text { 1. gaz ziemny }(85,5 \%) \\
\text { 2. oleje ropy naftowej }(6,9 \%) \\
\text { 3. przędza bawełniana }(1,7 \%) \\
\text { 4. bawełna surowa }(1,2 \%) \\
\text { 5. siarka niesublimowana }(0,7 \%)\end{array}$ \\
\hline Uzbekistan & $\begin{array}{l}\text { 1. klejnoty, metale szlachetne } \\
(30,8 \%) \\
\text { 2. paliwa mineralne, w tym ropa } \\
\text { naftowa }(19,9 \%) \\
\text { 3. bawełna }(11 \%) \\
\text { 4. miedź }(6,9 \%) \\
\text { 5. owoce, orzechy }(6,2 \%)\end{array}$ & $\begin{array}{l}\text { 1. złoto }(29,4 \%) \\
\text { 2. gaz ziemny }(19,3 \%) \\
\text { 3. przędza bawełniana }(8,4 \%) \\
\text { 4. } \text { miedź rafinowana i stopy } \\
\text { nieobrobione plastycznie }(5,2 \%) \\
\text { 5. } \text { polimery etylenu }(5,2 \%)\end{array}$ \\
\hline
\end{tabular}

Źródło: Opracowanie własne na podstawie danych worldstopexports.com (dostęp: 6.04.2020). 
Z jednej strony zarówno z punktu widzenia obecnego, jak i dalszego rozwoju państw Azji Centralnej powyższą sytuację w zakresie posiadanych przez nie przewag komparatywnych w handlu międzynarodowym, a także samej struktury towarowej eksportu tych państw należy ocenić jednoznacznie negatywnie. Biorąc bowiem pod uwagę specyfikę współczesnej zglobalizowanej gospodarki światowej oraz dynamiczne zmiany w obszarze międzynarodowej wymiany handlowej, w której coraz większą rolę odgrywają towary o wysokim i średnio-wysokim zaawansowaniu technologicznym, trudno oczekiwać realnych zmian dotychczasowego profilu konkurencyjnego państw Azji Centralnej, wyznaczanego struktura posiadanych przewag komparatywnych w eksporcie. Notabene, z punktu widzenia tych państw i ich dalszego rozwoju może to oznaczać, jeśli nie regres, to stagnację, $\mathrm{z}$ uwagi na istniejące poważne słabości strukturalne ich całych systemów ekonomiczno-społeczno-politycznych, jak również silną fluktuację cen na międzynarodowych rynkach surowcowych.

Z drugiej strony gospodarki państw Azji Centralnej mają względnie duży perspektywiczny potencjał, który odpowiednio wykorzystany mógłby realnie wzmocnić ich konkurencyjność na arenie międzynarodowej. Wielkim atutem jest ich położenie geograficzne pomiędzy olbrzymimi rynkami zbytu (bezpośrednio obok Chin i Rosji, we względnie bliskiej odległości od UE), jak również przebiegające przez ten region istniejące szlaki komunikacyjne. Co więcej, gospodarki tych państw mają potencjał inwestycyjny $\mathrm{i}$ to nie tylko $\mathrm{w}$ sektorze surowcowym, co należałoby bezwzględnie wykorzystać z punktu widzenia pozyskiwania kapitału oraz know-how. Niewatpliwie o przyszłym potencjalnym sukcesie w kontekście konkurencyjności gospodarek państw Azji Centralnej w handlu międzynarodowym zadecyduje umiejętność podjęcia skutecznych działań na rzecz zmiany miejsca tych gospodarek w międzynarodowym podziale pracy. Ponieważ jest to związane $\mathrm{z}$ ich przeorientowaniem w kierunku zwiększenia znaczenia wiedzy, technologii, innowacji, bez wsparcia kapitałowego z zewnątrz wydaje się raczej niemożliwe. Nie można bowiem na dłuższą metę opierać się tylko na przewagach komparatywnych w zakresie towarów o niskim stopniu zaawansowania technologicznego oraz niskiej wartości dodanej. Wyzwaniem w tym kontekście będzie także próba zmiany dotychczasowego miejsca tychże gospodarek w globalnych łańcuchach wartości.

\section{Możliwe obszary współpracy i/lub konkurencji w relacjach handlowych państw Azji Centralnej oraz UE i Chin}

Nie trzeba nikogo przekonywać, że z różnych względów, również pozaekonomicznych, od dłuższego czasu toczy się realna walka o region Azji Centralnej. Aktywny w niej udział biorą Chiny, Unia Europejska i Rosja, która cały czas postrzega ten 
region w kategoriach swojej tzw. bliskiej zagranicy i nie chce stracić tam swoich wieloletnich silnych wpływów. Jednym z wymiarów owej rywalizacji jest handel.

Jak wykazano wcześniej, z roku na rok rosną obroty handlowe państw Azji Centralnej zarówno z UE, jak i z Chinami, aczkolwiek dynamika wzrostu w tym drugim przypadku jest zdecydowanie silniejsza. W tym kontekście warto zadać pytanie o możliwe obszary współpracy/konkurencji we wzajemnej wymianie handlowej państw Azji Centralnej z UE oraz Chinami, uwzględniając przy tym profile konkurencyjne wszystkich stron (partnerów handlowych), determinowane posiadanymi ujawnionymi przewagami komparatywnymi (RCA).

Tabela 3. Ujawnione przewagi komparatywne (RCA) i ich siła dla państw Azji Centralnej, UE oraz Chin w handlu towarami według klasyfikacji SITC Rev2 na przestrzeni lat 2008-2018

\begin{tabular}{|c|c|c|c|c|c|c|c|}
\hline Rodzaj towaru & 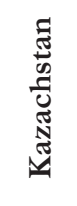 & 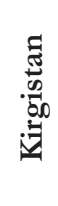 & 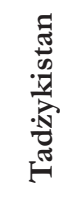 & 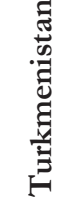 & 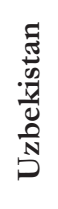 & 田 & 忌 \\
\hline Surowce rolne & - & ++ & +++ & +++ & ++ & - & - \\
\hline Chemikalia & - & - & - & - & - & + & - \\
\hline Żywność & - & ++ & - & - & + & + & - \\
\hline Paliwa & +++ & - & + & +++ & + & - & - \\
\hline $\begin{array}{l}\text { Maszyny i urządzenia } \\
\text { transportowe }\end{array}$ & - & - & - & - & - & + & + \\
\hline $\begin{array}{l}\text { Towary przetwórstwa } \\
\text { przemysłowego }\end{array}$ & - & - & - & - & - & + & + \\
\hline Rudy metali i metale & ++ & ++ & +++ & - & ++ & - & - \\
\hline Wyroby tekstylne & - & ++ & +++ & ++ & ++ & - & ++ \\
\hline
\end{tabular}

Legenda: ,-" - brak ujawnionych przewag komparatywnych; ,," - istnienie słabych ujawnionych przewag komparatywnych $(1<\mathrm{RCA}<2)$, , ++ " - istnienie średnich ujawnionych przewag komparatywnych $(2<$ RCA $<4)$, , +++ " - istnienie silnych ujawnionych przewag komparatywnych $($ RCA $>4)$.

Źródło: Opracowanie własne na podstawie danych United Nations Commodity Trade Statistics Database.

Z przeprowadzonych autorskich badań nad konkurencyjnością państw Azji Centralnej, EU i Chin, z wykorzystaniem metody analizy ujawnionych przewag komparatywnych B. Balassy dla handlu towarami według klasyfikacji SITC Rev2 na przestrzeni lat 2008-2018, jednoznacznie wynika, że w bardzo dużym stopniu posiadane przewagi komparatywne z jednej strony państw Azji Centralnej, z drugiej UE oraz Chin są w stosunku do siebie komplementarne. Zatem w sposób naturalny, biorąc pod uwagę wzajemną wymianę handlowa, występują obiektywne przesłanki 
do oczekiwania rozwoju i pogłębiania wzajemnej współpracy handlowej. Jest ona bowiem korzystna dla obydwu stron.

$Z$ jednej strony państwa Azji Centralnej są silnie konkurencyjne na arenie międzynarodowej w handlu surowcami rolnymi (wszystkie, z wyjątkiem tylko Kazachstanu), paliwami (wszystkie, $z$ wyjątkiem tylko Kirgistanu), rudami metali oraz metalami (wszystkie, z wyjątkiem tylko Turkmenistanu). W przypadku każdej z tych kategorii grup towarowych ani UE, ani Chiny nie maja żadnych przewag komparatywnych (nie sa w tym zakresie konkurencyjne).

Z drugiej strony państwa Azji Centralnej nie są konkurencyjne (nie mają żadnych przewag komparatywnych) w handlu chemikaliami, maszynami i urządzeniami transportowymi, a także towarami przetwórstwa przemysłowego. Z kolei w handlu tymi grupami towarów przewagi komparatywne mają: UE w przypadku chemikaliów, zaś w przypadku dwóch pozostałych wskazanych grup towarowych zarówno UE, jak i Chiny. Widać zatem bardzo wyraźnie wzajemne uzupełnianie się tych gospodarek. Państwa Azji Centralnej są konkurencyjne w handlu towarami o niskim stopniu przetworzenia i wartości dodanej, głównie surowcami, zaś UE i Chiny sa konkurencyjne w handlu towarami o wysokim stopniu przetworzenia i wartości dodanej. Posiadane przewagi komparatywne w powyższym zakresie, zarówno jednej, jak i drugiej strony, znajdują swoje odzwierciedlenie w strukturze towarowej handlu państw Azji Centralnej z UE i Chinami.

Warto też zwrócić uwagę na wyroby tekstylne. W tym zakresie przewagi komparatywne, i to stosunkowo silne, mają wszystkie państwa Azji Centralnej, za wyjątkiem Kazachstanu, oraz tradycyjnie Chiny. Jest to zatem naturalne, a jednocześnie jedyne pole rywalizacji pomiędzy państwami Azji Centralnej a Chinami. Nie wpływa ono na fakt, że z uwagi na komplementarne struktury posiadanych przewag komparatywnych w handlu międzynarodowym więcej łączy te państwa, aniżeli dzieli w kontekście wzajemnych korzyści z wymiany handlowej.

\section{Podsumowanie}

Dynamika współczesnych stosunków gospodarczych na przestrzeni ostatniej dekady znacznie przyspieszała. Było to bezpośrednią konsekwencją zarówno dynamicznych procesów globalizacji, internacjonalizacji działalności gospodarczej, wzrostu kooperencji międzynarodowej w ramach globalnych łańcuchów wartości (GVC) czy rewolucji ICT, jak i towarzyszącej temu wszystkiemu liberalizacji stosunków ekonomicznych, prowadzącej do istotnych zmian stopnia oraz charakteru międzynarodowych powiązań. Ważnym czynnikiem jest także aspekt geopolityczny tych procesów, związany z aspiracjami poszczególnych państw na arenie międzynarodowej. Ponadto współcześnie mamy do czynienia z takimi regionami świata, które 
stanowią swoiste pole walki o wpływy i pieniądze. Jednym z takich obszarów są państwa Azji Centralnej (Kazachstan, Kirgistan, Tadżykistan, Turkmenistan i Uzbekistan). O wpływy w nich od lat rywalizują Chiny i Rosja, ale także Unia Europejska przejawia duże zainteresowanie rozwojem współpracy gospodarczej z tym regionem $z$ uwagi na jego geostrategiczne położenie oraz posiadane obfite zasoby surowców naturalnych, zwłaszcza energetycznych.

W kontekście powyższego zasadne było przeprowadzenie analizy poziomu konkurencyjności państw Azji Centralnej, a zwłaszcza określenie profili konkurencyjnych ich gospodarek, zdeterminowanych przez posiadane tzw. ujawnione przewagi komparatywne (RCA), w celu zidentyfikowania potencjalnych obszarów współpracy i/lub rywalizacji krajów tego regionu z UE oraz Chinami. Z dokonanej analizy jednoznacznie wynika, że poziom konkurencyjności gospodarek państw Azji Centralnej we współczesnym handlu międzynarodowym jest stosunkowo niski i do tego mocno ograniczony co do struktury posiadanych przewag komparatywnych. Posiadają one bowiem owe przewagi jedynie w zakresie towarów o niskim stopniu zaawansowania technologicznego, niskiej wartości dodanej, kapitałochłonnych oraz pochodzących z przemysłów wykorzystujących średnio wykwalifikowanych pracowników fizycznych. Sytuację taką należy ocenić negatywnie z punktu widzenia ich dalszego rozwoju w warunkach współczesnej gospodarki światowej.

Niemniej jednak posiadane przewagi komparatywne w handlu międzynarodowym z jednej strony państw Azji Centralnej, z drugiej UE i Chin, będąc w stosunku do siebie komplementarne, stwarzają obiektywne przesłanki do oczekiwania rozwoju i pogłębiania wzajemnej współpracy handlowej, która będzie korzystna dla każdej ze stron. W kontekście zaś potencjalnego dalszego rozwoju wzajemnej współpracy handlowej, przy zachowaniu dotychczasowych trendów zmian, z dużym prawdopodobieństwem można założyć, że nadal będzie rosło znaczenie Chin jako partnera handlowego państw Azji Centralnej.

\section{SUMMARY}

\section{COMPETITIVENESS OF CENTRAL ASIAN COUNTRIES IN THEIR TRADE RELATIONS WITH THE EUROPEAN UNION AND CHINA}

At the time of growing economic competition between the superpowers, including the European Union and China, the Central Asia (CA) region, comprising the countries of Kazakhstan, Kyrgyzstan (Kyrgyz Republic), Tajikistan, Turkmenistan, Uzbekistan, is gaining special importance. In recent years, it is in particular China that has been very active in this region, also due to the implementation of its flagship Belt and Road Initiative. 
The purpose of the article is: 1) to establish the importance of the EU and China as export markets for goods from the countries of Central Asia, 2) to determine the competitive profiles of CA countries, 3) to identify potential areas of cooperation and/or competition in CA countries' trade relations with the EU and China.

The article shows that the international trade competitiveness of CA countries is relatively low and very limited to the structure of their comparative advantages. Yet, being complementary to one another, the comparative advantages possessed by the CA countries and by the EU and China provide grounds to assume that there are objective premises for the development and intensification of mutual trade cooperation, which will be beneficial to each of the parties concerned. 